\section{ECONOMICS}

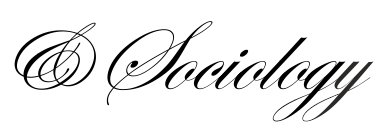

Nguyen, TTN., \& Luu, TMN. (2019). Linking transformational leadership and organizational performance: An empirical investigation of manufacturing firms in Vietnam. Economics and Sociology, 12(2), 170-191. doi:10.14254/2071-

789X.2019/12-2/10

\title{
LINKING TRANSFORMATIONAL LEADERSHIP AND ORGANIZATIONAL PERFORMANCE: AN EMPIRICAL INVESTIGATION OF MANUFACTURING FIRMS IN VIETNAM
}

\begin{abstract}
Thi-Trang-Nhung Nguyen, Hanoi University of Industry, 298 Cau Dien Street, Bac Tu Liem District, Hanoi, Vietnam E-mail: nguyenthitrangnhung@baui.edu.vn
\end{abstract}

\author{
Thi-Minh-Ngoc Luu, \\ University of Economics and \\ Business, Vietnam National \\ University, Hanoi, \\ 144 Xuan Thuy, Cau Giay, \\ Hanoi, Vietnam \\ E-mail:1tmngoc@vnu.edu.vn \\ Received: November, 2018 \\ 1st Revision: April, 2019 \\ Accepted: May, 2019
}

DOI: $10.14254 / 2071-$

789X.2019/12-2/10

JEL Classification: M12, J53

\begin{abstract}
The study highlight the implications of Transformational Leadership, examining its role in predicting Organizational Performance. The study also investigates the mediating role of Organizational Learning, Organizational Innovation, and Organizational Culture. Although these mediate relationships are very important for improving Organizational Performance, prior studies have not usually examined them. A study was carried out on a sample including 314 Vietnamese manufacturing firms. The findings indicated that Transformational Leadership can foster Organizational Performance through Organizational Learning, Organizational Innovation, and Organizational Culture. Furthermore, Organizational Learning and Organizational Culture influence Organizational Performance positively, both directly and indirectly through Organizational Innovation. The findings revealed that Organizational Innovation has a positive relationship with Organizational Performance.
\end{abstract}

Keywords: transformational leadership, organizational innovation, organizational learning, organizational culture, organizational performance, Vietnam.

\section{Introduction}

According to Burns (1978), leadership can be transactional or transformational. Transactional leadership is the style of leadership that involves an exchange relationship between leaders and followers that focuses on their own interests so that employees receive wages or prestige for complying with a leader's wishes. In contrast, Transformational Leadership focuses on the consciousness of collective interests among followers and help them attain organizational collective goals (Bass \& Avolio, 2000). Transactional and transformational behavior are used at different levels by leaders. Every leader may have both transformational and transactional behavior but if they want to remain effective, leaders need 
to become more transformational and less transactional (Bass, 1999). In this paper, the authors focus on Transformational Leadership because of its effects.

Bass (1995) developed transformational theory from Burns (1978) that emphasized on the importance of followers' job satisfaction and their success. Moreover, when followers balance their own success and organizations' values and goals, they contribute to developing better work context (Podsakoff, MacKenzie, \& Bommer, 1996). Therefore, transformational leaders influence followers goals and beliefs in order to enhance degrees of performance among individuals in organization (Yukl, 2013). Transformational leaders inspire followers to reach their highest levels of achievement and managerial performance (Nguyen, Mia, Winata, \& Chong, 2017). Reviewing literature on leader characteristics, we have found that Transformational Leadership is the most effective among leadership styles (Thomson, Rawson, Slade, \& Bledsoe, 2016). Transformational Leadership through charisma provides inspiration and intellectual stimulation, both being important for Organizational Innovation (Elkins \& Keller, 2003). On the one hand, leaders motivate their followers through providing inspiration. On the other hand, leaders promote employees' intelligence, knowledge, skills and learning through intensifying intellectual stimulation (García-Morales, JiménezBarrionuevo, \& Gutiérrez-Gutiérrez, 2012). Moreover, leaders with transformational behavior tend to change Organizational Culture (Bass, 1999). Most studies have only investigated the immediate relationship between Transformational Leadership and performance. On the other hand, a lot of studies investigated the relationship between Transformational Leadership and organizational leadership through a mediate variable. Such as culture and motivation (Syafii, Thoyib, Nimran, \& Djumahir, 2015), innovation (Samad, 2012), knowledge management (Birasnav, 2014), trust and commitment (Yuan, Nguyen, \& Vu, 2017). Transformational Leadership, Organizational Learning, innovation, culture, and performance relate positively together. However, few empirical research explored the interrelationships between these five concepts, particularly in Vietnamese context. Moreover, notwithstanding the importance that Organizational Learning, Organizational Innovation, and Organizational Culture seem to influence the relationship between Transformational Leadership and Organizational Performance too, while understanding of the effect from all of these variables in this relationship remains to be inadequate. Moreover, García-Morales et al. (2012) indicated that understanding of the processes through which the leader exerts this influence is still limited and largely speculative. Based on the above basics and suggestions García-Morales et al., (2012), we have decided to analyze the empirical influences of Transformational Leadership on Organizational Performance through the intermediate influence of Organizational Learning, Organizational Innovation, and Organizational Culture.

Organizational Learning can be defined as the process when the firm improves new knowledge and insights based on available experiences of the people in the organization so as to influence behavior, improve firm's capabilities and maintain or improve performance (Dibella, Nevis, \& Gould, 1996, Fiol \& Lyles, 1985). The improvement of new knowledge and insights is a key factor for Organizational Learning and is basic for maintaining competitive advantage and enhancing Organizational Performance (Brockman \& Morgan, 2003, Fiol \& Lyles, 1985).

The empirical research investigating the positive relationship between Organizational Learning and innovation include (Aragón-Correa, García-Morales, \& Cordón-Pozo, 2007a, García-Morales et al., 2012, Jiménez-Jiménez \& Sanz-Valle, 2011). Organizational Learning leads to generation of new knowledge and ideas, and also encourages their further use (Aragón-Correa et al., 2007a).

Organizational Culture can be defined as a set of values and beliefs shared by members of an organization that influences their behavior (Schein, 2010). Because of the influences of Organizational Culture on employees' behavior, it can lead to accepting 
innovation as a basic value of organization and having a strong attachment to it (Hartmann, 2006). Therefore, Organizational Culture enhances Organizational Innovation and that innovation is connected with performance. So, Organizational Culture immediately relates with performance. Besides, literature on the topic suggests that types of culture relate directly to performance in different ways such as cultural orientations adaptability and stability (Gordon \& DiTomaso, 1992), achievement orientation (Athena Xenikou \& Maria Simosi, 2006), market culture (Zollo \& Winter, 2002). Empirical research has also provided evidence of the positive relationship between culture and innovation (Büschgens, Bausch, \& Balkin, 2013, Lau \& Ngo, 2004, Naranjo-Valencia, Jiménez-Jiménez, \& Sanz-Valle, 2016).

Many authors defined innovation concepts in a variety of ways. This paper uses the definition of innovation developed by Jiménez-Jiménez \& Sanz-Valle (2011): Innovation is the process that includes the adoption of any new product, process and administrative innovation. Although there is clear evidence that firm innovation plays a critical role in remaining and improving Organizational Performance, many firms do not or cannot develop innovations (Aragón-Correa et al., 2007a). Many authors have tried to find the answer to the question on how to develop innovation. However, to answer the question is "beyond semiautomatic stimulus-response processes" (Zollo \& Winter, 2002).

The literature emphasizes the key role that Organizational Learning, innovation and Organizational Culture play in firm's survival and effective performance. Thus, our study has beenconducted to explore Transformational Leadership's impacts on Organizational Performance through the mediating role of Organizational Learning, Organizational Innovation, and Organizational Culture. We expect that the study will contribute new knowledge on how Transformational Leadership may effect of the concept of Organizational Performance (Figure 1).

Our study attempts to address the following research questions:

RQ1. Does Transformational Leadership influence Organizational Performance?

RQ2. Do Organizational Learning, Innovation, and Culture play a mediating role between Transformational Leadership and Organizational Performance?

RQ3. Which factor has a greater influence on Organizational Performance?

To answer these questions, structural equations modeling is applied to investigate the degree of influence that each variable has on the others, based on the survey of 314 respondents from 314 manufacturing firms in three biggest cities in Vietnam. By answering the above questions, the first goal of this study is to analyze and provide empirical evidence about the relationship between Transformational Leadership, aspects of Organizational Learning, Innovation, Culture and Performance. For achievement of the second goal, this study not only estimates direct influences but also explores, more specifically, the indirect impacts of mediating variables on Organizational Performance. Therefore, the article is expected to provide specific and effective solutions for directors or managers in what concerns performance of organizations.

In order to achieve these objectives, the article is organized in four main sections. First, literature review on Transformational Leadership, Organizational Learning, Innovation, and Organizational Culture is presented, then the hypotheses were developed. Second, the research methodology is given. Afterwards, the field study analyses were given comparatively with the results described in the literature review aboe. Finally, the results of the study, strengths and weaknesses, research implications, and future research recommendations are outlined. 


\section{Hypotheses}

\subsection{The influences of transformational leadership on organizational learning, organizational innovation, and organizational culture}

Scholars paid great attention to Transformational Leadership, as it had emerged as one of the most influential leadership theories (Mhatre \& Riggio, 2014). Therefore, exploring the influence of Transformational Leadership on Organizational Learning, Organizational Innovation and Organizational Culture play a crucial role in finding an effective way to promote these factors.

Many researchers have stated that leadership and Organizational Learning have a relationship (Senge, 1999, Tushman \& Nadler, 1986). If traditional leadership makes the learning of organizational teams difficult by high individualism and complex systems, in contrast, Transformational Leadership encourages subordinate's participation in collective decisions and activities (Bass, 1990).

Transformational Leadership is described as a style that plays a key role in developing Organizational Learning (Slater \& Narver, 1995). Organizational Learning occurs when the managers create ideas and share them to achieve a commitment to learning among members (Ulrich, Jick, \& Glinow, 1993). A manager not committed to learning will make organizational suspicion (Maani \& Benton, 1999).

Features of Transformational Leadership relate to Organizational Learning. Transformational leaders perceive that their role has more coordination feature than command and control feature (Barczak \& Wilemon, 1992). They create collective processes of Organizational Learning and consolidates trust between organization members and leaders (Manz, Barstein, Hostager, \& Shapiro, 1989, Scott \& Bruce, 1994). Transformational leaders provide inspiration by motivating their followers, mainly through communication of high expectations and stimulation of people's intelligence, knowledge, and learning ability (Chang, Bai, \& Li, 2015).

\section{H1. Transformational Leadership is positively related to Organizational Learning.}

The leader plays an important role in Organizational Innovation and in creating an environment that encourages innovative capability (Van de Ven, 1986). Likewise, GarcíaMorales, Llorens-Montes, \& Verdú-Jover (2006) stated that leader characteristics and leadership style are necessary to encouraging this innovative capability. On the other way, García-Morales et al. (2006) also claimed that Transformational Leadership style encourages Organizational Innovation better than transactional leadership style. It has a close relation to a variety of positive outcomes and is considered a crucial factor towards change capacity (Yasir, Imran, Irshad, Mohamad, \& Khan, 2016). Transformational leaders are able to inspire their employees to explore new technologies and innovative ideas (Chang et al., 2015).

Transformational Leadership has several features that relate to firm innovation. Transformational leaders obtain effective communication and share values through having an interactive vision and paying maximum attention (Quinn, 1986). Furthermore, they also encouraged a suitable climate for innovative teams (Tushman \& Nadler, 1986). All these features together allow a better understanding of the strong relationship between Transformational Leadership and Organizational Innovation. 
H2. Transformational Leadership is positively related to Organizational Innovation.

Some earlier research validated that leadership style and Organizational Culture have a positive association. The leader plays an important part in beginning the culture creation process and is the person who manages and changes the Organizational Culture (Schein, 2010). A basic characteristic that discriminates between Transformational Leadership and Transformational Leadership is culture. Transactional leaders always work with the available culture, in contrast, transformational leaders frequently make efforts to change the Organizational Culture to accord with their vision. Therefore, perfect leaders are a person who shows Transformational Leadership characteristics that permit them to vary respects of Organizational Culture in order to decrease Organizational Performance (Bass, Avolio, Jung, \& Berson, 2003)

Cultural orientation is achieved when there is a direct effect of Transformational Leadership. Cultural orientation directly affects Organizational Performance and that Transformational Leadership has an indirect positive effect on performance through its impacts on achievement orientation (Athena Xenikou \& Maria Simosi, 2006).

H3. Transformational Leadership is positively related to Organizational Culture.

\subsection{The influences of organizational learning on organizational innovation}

The literature does not state a positive association of Organizational Learning on performance but affirms that innovation mediates this relation. Moreover, some authors claim that Organizational Learning helps the company to develop capabilities in order to enhance innovation and that innovation has a positive effect on performance (Baker \& Sinkula, 1999).

Organizational Innovation is made by Organizational Learning and focus on the knowledge base that the organization possesses (Cohen \& Levinthal, 1990, Nonaka \& Takeuchi, 1995). In order to service in the intensely competitive market, the organization needs to innovate continuously, in that background, Organizational Learning plays a strategic variable that helps the organization to introduce new products or create new markets (Cefis \& Marsili, 2005). Therefore, it is necessary to stimulate the development of factors that contribute to innovation.

Organizational Learning "supports creativity, inspires new knowledge and ideas and increases the potential to understand and apply them, favors organizational intelligence and (with the culture) forms a background for orientation to Organizational Innovation" (GarcíaMorales, Ruiz-Moreno, \& Llorens-Montes, 2007). The higher the levels of commitment to learning are the greater the innovative orientation and activity are (Ussahawanitchakit, 2008).

H4. Organizational Learning is positively related to Organizational Innovation.

\subsection{The influences of organizational culture on organizational innovation}

The relationship between Organizational Culture and Organizational Innovation has been a subject that has received relatively much attention from organizational research over the last decade. Recently, one of the variables is believed to have great influences on innovation is Organizational Culture (Büschgens et al., 2013, Lin, McDonough, Lin, \& Lin, 2013). Organizational Culture is the values, beliefs, and hidden assumptions that the members of an organization have in common (Miron, Erez, \& Naveh, 2004). The members of the organization can be encouraged to have innovative behavior through culture because culture can tend them to accept innovation as a basic value of the organization (Hartmann, 2006). 
The core of the Organizational Culture is shared values, and that values are shared by organization members (Saffold, 1988). The internalization of organizational values should tend to a balance of the goals of management and individual followers. Thus, it plays an important function because the activities of individuals play a basic role in shaping innovation processes (Salvato, 2009).

H5. Organizational Culture is positively related to Organizational Innovation.

\subsection{The influences of organizational learning, organizational innovation and organizational culture on organizational performance}

Organizational Learning is a key variable for maintaining competitive advantages and promoting Organizational Performance. Learning orientation has a direct association with firm performance (Baker \& Sinkula, 1999). The Organizational Learning process has five steps: obtaining information, sharing information, interpreting shared information, creating memory and procedural memory, and all of them have a positive relationship with company`s performance (Tippins \& Sohi, 2003).

According to what García-Morales, Lloréns-Montes, \& Verdú-Jover (2008) asserted: it is not true to affirm that the more Organizational Learning increases, the more Organizational Performance grow since learning may not always improve an organization's outcome. However, generally speaking, Organizational Learning has a positive association with performance and this relationship usually occurs in both technological companies and manufacturing firms (Argyris \& Schon, 1995, Fiol \& Lyles, 1985).

The result of today`s Organizational Learning process is future performance, and organizations should encourage the spirit of Organizational Learning, even sacrifice today's performance to achieve future performance (Senge, 1999).

In conclusion, all the empirical findings, and evidence show that:

H6. Organizational Learning is positively related to Organizational Performance.

Rapidly changing technologies play an important role in sharing today's competitive climate and product innovation. Innovation is one of the important means to achieve superior performance in a competitive environment (Lyon \& Ferrier, 2002). The more valuable/ imperfectly imitable/ rare Organizational Innovation are, the higher performance will be (García-Morales et al., 2006). Innovation has a considerable impact on corporate performance by producing an improved market position that conveys competitive advantage and superior performance (Kalmuk \& Acar, 2015).

There are different types of innovation, but the most accepted types of innovation include technological innovation and administrative innovation (Damanpour, 1991). According to Dewar \& Dutton (1986) and Hage (1980), technological innovation relates to new processes/ products/ services while administrative innovation relates to new procedures/ policies/ administrative structures. Innovation helps the company cope with difficulties of the dynamic external environment and is one of the key elements for company`s long - term development. Prior empirical studies showed a positive effect of innovation on firm performance (Gunday, Ulusoy, Kilic, \& Alpkan, 2011, Naranjo-Valencia et al., 2016, Samad, 2012). The innovative firm can develop new products faster than non-innovative firm and they can achieve better advantage of market opportunities and therefore increase Organizational Performance (Brown \& Eisenhardt, 1995). Thus: 
H7. Organizational Innovation is positively related to Organizational Performance.

The above parts propose that Organizational Culture increases Organizational Innovation and that innovation is related to Organizational Performance. Thus, it is possible to affirm that innovation mediates the association between Organizational Culture and performance (Naranjo-Valencia et al., 2016). But, researchers frequently assumed that Organizational Culture is directly linked to the performance of an organization because of the influences of culture on the behavior of the organizational members (Denison, 1990; Martins \& Terblanche, 2003; Hofstede \& Bond, 1988). Furthermore, according to Coyne (1986), culture is an important resource of sustainable competitive advantages because culture is valuable, rare, and is difficult for competitors to imitate. Simultaneously, effectiveness and efficiency will be affected immediately when changes in cultural traits occur (Kotter \& Heskett, 2011).

Moreover, many researchers stated that different types of culture have a different effect on performance. Deshpandé, Farley, \& Jr (1993) studied corporate, customer orientation and innovativeness in Japanese firms. They affirmed that the market culture is related to better performance, followed by adhocracy culture. On the other hand, the clan culture and the hierarchy culture are related to poor performance. Gordon \& DiTomaso (1992) predicted corporate performance from Organizational Culture. Their research studied the effects of the cultural orientation adaptability and stability on financial performance based on the sample of a number of U.S. firms. The result stated that companies that emphasize adaptability have better financial performance than companies that emphasize stability. In addition, Athena Xenikou \& Maria Simosi (2006) used a sample of Greek organizations to conclude that market culture (the achievement orientation) has an association with performance whereas clan culture (the humanistic orientation) has not. This is homogeneous with the research result of Deshpandé et al. (1993).

This study highlights the theoretical relationships between Organizational Culture and Organizational Performance and later test empirically which Organizational Culture aspect provides a significant effect on Organizational Performance.

H8. Organizational Culture is positively related to Organizational Performance.

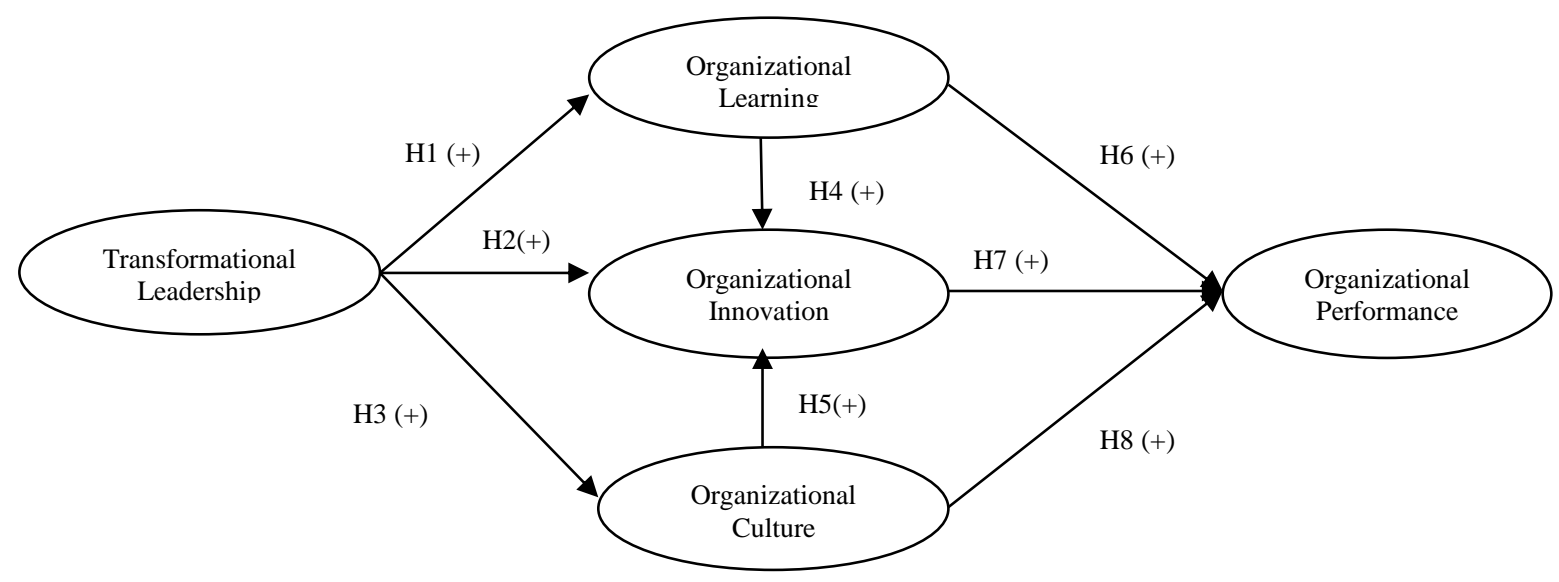

Figure 1. The theoretical model

Based on the literature review, the theoretical framework is proposed as shown in Figure 1. This figure presents a model consisting of eight hypotheses about how Transformational Leadership, Organizational Learning and Organizational Culture 
simultaneously condition firm innovation. We also propose an indirect relationship between Transformational Leadership and innovation through Organizational Learning and Organizational Culture. We recognize that other variables might be considered in such a model, however, it was necessary to limit our model to be able to offer empirical evidence for our arguments, and we selected these three factors to represent a focus on collective explanations for innovation activity, respectively. Moreover, our aim here was simultaneous consideration of these relevant antecedents of firm innovation. Additionally, we developed hypotheses about the effect of innovation, learning and culture on performance. Figure 1 illustrates the proposed model.

\section{Method}

\subsection{Sample and procedures}

The population for this study consists of Vietnamese firms from the manufacturing sectors. The study focuses on these sectors because they represent a bigger percentage, billing volume and employment proportion in the Vietnamese economy. Moreover, using a sample of firms is relatively homogeneous with literature review, minimizes the impact of variables that cannot be controlled in the empirical research. Vietnamese market is an emerging market and relatively developed in ASEAN area. Vietnam has a better rate of growth in recent years. Becoming a membership of TPP (Trans-Pacific Partnership) in February 2016 is a great opportunity and challenge for Vietnam to join global market. However, Vietnam is a country that has received relatively little attention from organizational researchers. Thus, this study focuses on Vietnam as a new context for research.

Drawing in our interviews with five CEOs and five academics interested in the topic and familiar with the Vietnamese market, we developed a structured questionnaire to investigate how organizations face learning, innovation and culture issues. These developmental interviewees did not provide data for the empirical investigation. We then established a reliable list of the CEOs of the organizations, with the help of the Vietnamese General Department of Taxation. The study uses CEOs as the key informants because they absorb information from many channels of organization and therefore are a very valuable source for analysis. They also play an important role in determining the types of behavior that are expected and supported.

The research population consisted of firms with the greatest turnover in three biggest cities in Vietnam (Hanoi, Ho Chi Minh, and Da Nang) according to The Vietnamese General Department of Taxation database in manufacturing sector. A sample 1200 organizations was selected randomly from this source. The authors sent to the CEOs of 1200 randomly selected organizations a cover letter through mail survey (146 returned emails due to the incorrect email address). We used this method rather than interviews because a mailed survey enable us to reach a greater number of firms at a lower cost, put less pressure for an immediate response on the potential informant, and gave respondents a greater feeling of autonomy. To reduce possible desirability bias, we promised that we would keep all individual responses completely confidential and confirmed that our analyses would be restricted to an aggregated level that would prevent the identification of any organization. Each CEO received 2 reminders by email if they had not yet answered a mail survey. CEOs were asked not to answer the cover letter whenever they felt not having knowledge of the variables in the questions. This work decreased the percentage of responses, in contrast, the reliability and validity of the received questionnaires increased. Finally, $435 \mathrm{CEOs}$ responded to the questionnaire, but the research only used 314 questionnaires because of missing values. 
Therefore, total CEOs participated in this study were 314 CEOs who represented 314 manufacturing firms in three biggest cities in Vietnam.

The questionnaire includes five parts: Transformational Leadership, Organizational Learning, innovation, culture, and performance. The questionnaire utilizes a five-point Likert scale. The purpose of this paper is to study these links by using the sample of manufacturing firms.

\subsection{Measures}

The structure and content of survey were built based on comprehensive review of the existing literature. To guarantee equivalence of meanings and ensure translation quality of constructs, two independent bilingual scholars translated the survey from English to Vietnamese then translated it back. All of the following measures consist of items with Likert scale from 1 "totally disagree" to 5 "totally agree". They are operationalized as follows:

\subsubsection{Transformational Leadership}

We adopted four items used in McColl-Kennedy \& Anderson (2002) to measure Transformational Leadership. These items are suitable for this present research. The questionnaire required the CEOs indicate their perceptions about their behavior of Transformational Leadership in the organization. A sample item is "increases employees' level of enthusiasm". The authors used a confirmatory factor analysis to validate this scale, which required deletion of Item 1 (Give personal attention to each sales representative). The result stated that Chi-square=7.36, Normed Fit Index [NFI]=.997, Goodness of Fit Index $[\mathrm{GFI}]=.997$, Comparative Fit Index $[\mathrm{CFI}]=1$, Incremental Fit Index $[\mathrm{IFI}]=1$. The scale is unidimensional. This procedure allowed selection of three items. The Cronbach's alpha for Transformational Leadership (after deleting item 1) was .910 indicating good reliability (alpha > .70).

\subsubsection{Organizational Learning}

To assess Organizational Learning, we used four items developed by Aragón-Correa et al., (2007a), García-Morales et al., (2006), Víctor J. García-Morales et al., (2008), GarcíaMorales et al., (2012). These items are duly adapted to this present research. A sample item is "The organization's members have acquired some critical capacities and skills that provided competitive advantage". The authors develop a confirmatory factor analysis to validate the Organizational Learning (Chi-square $=.328, \mathrm{NFI}=.99$, GFI $=.99, \mathrm{CFI}=.99, \mathrm{IFI}=.99$ ) and show that the scale is unidimensional and has high validity and reliability (Cronbach's alpha=.913).

\subsubsection{Organizational Culture}

This research used a scale of 11 items to measure Organizational Culture developed by Shao, Feng, \& Liu (2012). A sample item is "The glue in our firm is innovation and development". These items are duly adapted to this present research. These items are duly adapted to this present research. The authors develop a confirmatory factor analysis which required deletion of Item 11 to validate the Organizational Culture (Chi-square=93.240, $\mathrm{NFI}=.945, \mathrm{GFI}=.945, \mathrm{CFI}=.965, \mathrm{IFI}=.965)$ and show that the scale is unidimensional. The Cronbach's alpha for Organizational Culture (after deleting item 11) was .918 indicating high reliability (Alpha>.70). 


\subsubsection{Organizational Innovation}

Our research used a scale of nine items to measure Organizational Innovation developed by Antoncic \& Hisrich (2001). A sample item is "Organization's emphasis on developing new products or services". These items are duly adapted to this present research. The authors develop a confirmatory factor analysis to validate the Organizational Innovation (Chi-square $=86.83, \mathrm{NFI}=.969, \mathrm{GFI}=.942, \mathrm{CFI}=.978, \mathrm{IFI}=.978$ ) and show that the scale is unidimensional. The Cronbach`s Alpha for Organizational Innovation was .959 indicating high reliability (alpha $>.70)$.

\subsubsection{Organizational Performance}

We adopted Murray \& Kotabe (1999) five-item Organizational Performance Scale. A sample item is "Organization's market share in its main products and markets". These items are duly adapted to this present research. The authors develop a confirmatory factor analysis to validate the Organizational Performance (Chi-square $=3.190, \mathrm{NFI}=.997, \mathrm{GFI}=.996, \mathrm{CFI}=1$, $\mathrm{IFI}=1$ ) and show that the scale is unidimensional and has high validity and reliability $($ Cronbach's alpha $=.925)$.

\subsubsection{Control variables}

Size may affect an organization's ability to learn or to innovate (Aragón-Correa, García-Morales, \& Cordón-Pozo, 2007b). The size indicators initially used for this study were firm income and number of employees. Correlation coefficients between these sources were strong and significant. Besides, because size and income were highly correlated, we selected number of employees only in our study.

\subsection{Data analysis methodology}

Given the existence of an exogenous latent variable (Transformational Leadership), a first-grade endogenous latent variable (Organizational Learning and Organizational Culture) and second-grade endogenous latent variable (Organizational Innovation and Organizational Performance) are used. Data analysis was conducted by using SPSS and AMOS version 22. Confirmatory factor analysis (CFA) was implemented to examine the validity and reliability of the constructs. Structural equation modeling (SEM) via AMOS 22 was employed to test the hypotheses. We first estimated the fit of the measurement model using confirmatory factor analysis (CFA) and then evaluated the fit of the structural models. Overall model fit was examined by various fit indices, including root mean square error of approximation (RMSEA), incremental fit index (IFI), Tucker-Lewis index (TLI). And comparative fit index (CFI). The requirements of a reasonable model fit are met if RMSEA is below 0.08 (Browne \& Cudeck, 1992) and IFI, TLI, and CFI are above .90 (Bentler \& Bonett, 1980).

To test the mediating effects as hypothesized, we simultaneously tested the significance of both the paths from the independent variable (i.e., Transformational Leadership behavior) to the mediator (i.e., Organizational Learning, Organizational Innovation, and Organizational Culture), and the paths from the mediators to the outcome (Organizational Performance). 


\section{Results}

\subsection{Convergent and discriminant validity}

We conducted an EFA using principal axis factoring with Promax rotation to see if the observed variables loaded together as expected, were adequately correlated, and met criteria of reliability and validity. The results indicated that the KMO and Bartlett's test of sampling adequacy was significant and commonalities for each variable were sufficiently high $(\mathrm{KMO}=.933)$. Furthermore, as shown in Table 1, all the factor loadings were found to be significant at .001 levels (all above .594), the results suggest good discriminant validity. This indicates that the chosen variables were adequately correlated for factor analysis.

The Cronbach's alphas for the extracted factors are also shown in Table 1. All alphas were above .70 . All factors are reflective because their indicators are highly correlated are largely interchangeable.

Table 1. Item loading of the latent constructs

\begin{tabular}{|c|c|c|c|c|c|c|}
\hline Items & $\begin{array}{l}\text { Transformational } \\
\text { Leadership }\end{array}$ & $\begin{array}{l}\text { Organizational } \\
\text { Learning }\end{array}$ & $\begin{array}{c}\text { Organizational } \\
\text { Culture }\end{array}$ & $\begin{array}{l}\text { Organizational } \\
\text { Innovation }\end{array}$ & $\begin{array}{l}\text { Organizational } \\
\text { Performance }\end{array}$ & $\begin{array}{c}\text { Cronbachs } \\
\text { alpha }\end{array}$ \\
\hline TL2 & .913 & & & & & \multirow{3}{*}{.910} \\
\hline TL3 & .873 & & & & & \\
\hline TL4 & .819 & & & & & \\
\hline OL1 & & .903 & & & & \multirow{4}{*}{.913} \\
\hline OL2 & & .826 & & & & \\
\hline OL3 & & .800 & & & & \\
\hline OL4 & & .864 & & & & \\
\hline $\mathrm{OC} 1$ & & & .738 & & & \multirow{10}{*}{.918} \\
\hline OC2 & & & .726 & & & \\
\hline OC3 & & & .594 & & & \\
\hline OC4 & & & .795 & & & \\
\hline OC5 & & & .646 & & & \\
\hline OC6 & & & .800 & & & \\
\hline OC7 & & & .769 & & & \\
\hline OC8 & & & .770 & & & \\
\hline OC9 & & & .718 & & & \\
\hline OC10 & & & .676 & & & \\
\hline OI1 & & & & .841 & & \multirow{9}{*}{.959} \\
\hline OI2 & & & & .871 & & \\
\hline $\mathrm{OI} 3$ & & & & .906 & & \\
\hline OI4 & & & & .766 & & \\
\hline OI5 & & & & .854 & & \\
\hline OI6 & & & & .876 & & \\
\hline OI7 & & & & .901 & & \\
\hline OI8 & & & & .854 & & \\
\hline OI9 & & & & .779 & & \\
\hline OP1 & & & & & .855 & \multirow{5}{*}{.925} \\
\hline OP2 & & & & & .860 & \\
\hline OP3 & & & & & .871 & \\
\hline OP4 & & & & & .804 & \\
\hline OP5 & & & & & .830 & \\
\hline
\end{tabular}

Note: (1) Extraction Method: Principal Axis Factoring.

(2) Rotation Method: Promax with Kaiser Normalization. 
Since all measures were collected with the same survey instrument, we checked the common method bias through Harman's one-factor test. The 3 items of Transformational Leadership, 4 items of Organizational Learning, 9 items of Organizational Innovation, 10 items of Organizational Culture and 5 items measuring Organizational Performance were entered in a principal component factor analysis. The results indicated that the first factors in the model explained $32.726 \%$ of the variance. So, here, the common method bias was not an issue.

Moreover, Table 2 presents the mean, standard deviation, correlation among all the study variables as well as square root of AVE. Table 2 presents that Transformational Leadership is positively related to Organizational Learning ( $\mathrm{r}=.357)$, Organizational Culture $(\mathrm{r}=.305)$, Organizational Innovation $(\mathrm{r}=.414)$ and Organizational Performance $(\mathrm{r}=.423)$. Organizational Learning was positive related to Organizational Culture $(\mathrm{r}=.245)$, Organizational Innovation ( $\mathrm{r}=.289)$ and Organizational Performance $(\mathrm{r}=.353)$. Organizational Culture is positively related to Organizational Innovation $(r=.279)$ and Organizational Performance $(\mathrm{r}=.320)$. And Organizational Innovation is positively related to Organizational Performance (.278). Although these correlations are in the expected directions, they do not take into account the nested nature of the data. Therefore, we rely on SEM to test our hypotheses.

Furthermore, to test discriminant validity, we compared the square root of the AVE (on the diagonal in the matrix below) to all inter-factor correlations (Chin, Marcolin, \& Newsted, 2003). All factors demonstrate adequate discriminant validity because the square root of the average variance extracted of each latent construct is greater than that construct's correlation with other construct's.

Table 2. Correlations and average variances extracted from constructs

\begin{tabular}{llllllll}
\hline Variable & Mean & S.D & $\mathbf{1}$ & $\mathbf{2}$ & $\mathbf{3}$ & $\mathbf{4}$ & $\mathbf{5}$ \\
\hline 1.Transformational Leadership & 3.787 & .708 & $\mathbf{( . 8 7 9 )}$ & & & & \\
\hline 2.Organizational Learning & 3.627 & .847 & $.357^{* *}$ & $\mathbf{( . 8 5 2 )}$ & & & \\
\hline 3.Organizational Culture & 3.442 & .634 & $.305^{* *}$ & $.245^{* *}$ & $\mathbf{( . 7 2 9 )}$ & & \\
\hline 4.Organizational Innovation & 3.518 & .707 & $.414^{* *}$ & $.289^{* *}$ & $.279^{* *}$ & $(.847)$ & \\
\hline 5.Organizational Performance & 3.679 & .776 & $.423^{* *}$ & $.353^{* *}$ & $.320^{* *}$ & $.278^{* *}$ & $(.844)$ \\
\hline 6. Size & 2.3 & .564 & -.072 & -.020 & .064 & .008 & .056 \\
\hline
\end{tabular}

Note: $(1)^{* *}$ Correlation is significant at the .01 level (2-tailed). $\mathrm{N}=314$

(2) The square root of AVE for discriminant validity are in parentheses along the diagonal.

In order to check the fit of the five-factor model, we performed a CFA before testing the hypothesis. The five-factor model included Transformational Leadership, Organizational Learning, Organizational Innovation, Organizational Culture and Organizational Performance. The CFA for measurement model indicated the following indices: $\chi^{2}(419)=455.597, \mathrm{p}=.105, \mathrm{GFI}=.915, \mathrm{CFI}=.995, \mathrm{IFI}=.995, \mathrm{TLI}=.994, \mathrm{RMSEA}=.017$ (See Figure 2). The results perform a good fit between the measurement and the data collected. 


\section{RECENT ISSUES IN SOCIOLOGICAL RESEARCH}

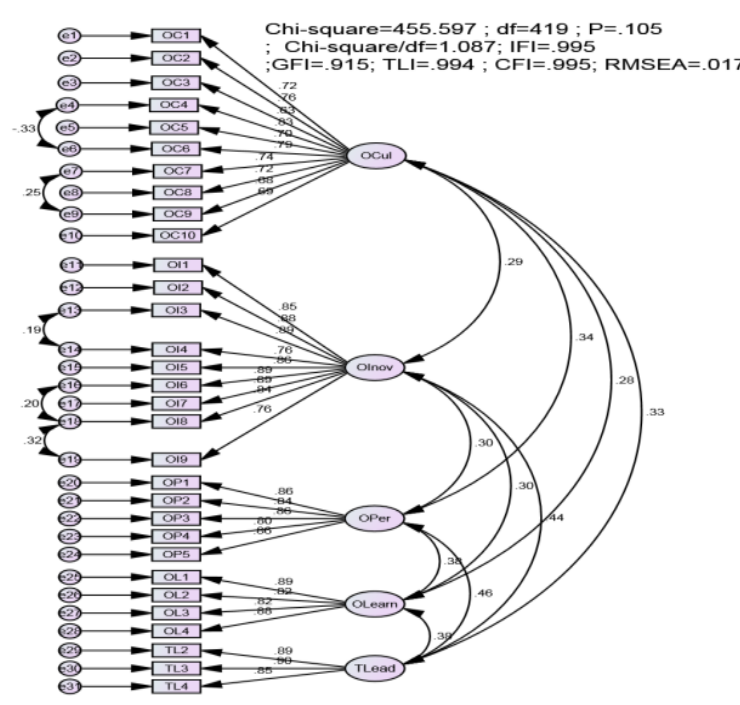

Figure 2. Confirmatory factor analysis

Table 3. Validity, reliability and internal consistency

\begin{tabular}{|c|c|c|c|c|c|c|c|}
\hline Variable & $\begin{array}{l}\text { No. of } \\
\text { items }\end{array}$ & Items & $\begin{array}{c}\text { Standardized factor } \\
\text { loadings }\end{array}$ & T-value & $\mathrm{R}^{2}$ & AVE & $\begin{array}{l}\text { Composite } \\
\text { reliability }\end{array}$ \\
\hline \multirow{3}{*}{$\begin{array}{l}\text { Transformational } \\
\text { Leadership }\end{array}$} & \multirow{3}{*}{3} & TL2 & $.887^{* * *}$ & f.p. & .787 & \multirow{3}{*}{.772} & \multirow{3}{*}{.911} \\
\hline & & TL3 & $.899^{* * *}$ & 21.590 & .808 & & \\
\hline & & TL4 & $.850^{* * * *}$ & 19.880 & .723 & & \\
\hline \multirow{4}{*}{$\begin{array}{l}\text { Organizational } \\
\text { Learning }\end{array}$} & & OL1 & $.885^{* * *}$ & f.p. & .783 & \multirow{4}{*}{.726} & \multirow{4}{*}{.914} \\
\hline & & OL2 & $.821^{* * *}$ & 18.748 & .674 & & \\
\hline & & OL3 & $.825^{* * *}$ & 18.895 & .680 & & \\
\hline & & OL4 & $.876^{* * *}$ & 20.983 & .767 & & \\
\hline \multirow{10}{*}{ Organizational Culture } & \multirow{10}{*}{10} & OC1 & $.725^{* * *}$ & f.p. & .525 & \multirow{10}{*}{.531} & \multirow{10}{*}{.918} \\
\hline & & $\mathrm{OC} 2$ & $.762^{* * *}$ & 13.285 & .580 & & \\
\hline & & OC3 & $.627^{* * *}$ & 10.863 & .393 & & \\
\hline & & OC4 & $.829^{* * * *}$ & 14.344 & .687 & & \\
\hline & & OC5 & $.705^{* * *}$ & 12.261 & .497 & & \\
\hline & & OC6 & $.788^{* * *}$ & 13.590 & 0.621 & & \\
\hline & & OC7 & $.745^{* * *}$ & 12.972 & 0.555 & & \\
\hline & & OC8 & $.721^{* * *}$ & 12.550 & .520 & & \\
\hline & & OC9 & $.675^{* * *}$ & 11.706 & .456 & & \\
\hline & & OC10 & $.686^{* * * *}$ & 11.919 & .470 & & \\
\hline \multirow{9}{*}{$\begin{array}{l}\text { Organizational } \\
\text { Innovation }\end{array}$} & \multirow{9}{*}{9} & OI1 & $.851^{* * *}$ & f.p. & .725 & \multirow{9}{*}{.718} & \multirow{9}{*}{.958} \\
\hline & & OI2 & $.879^{* * * *}$ & 20.961 & 0.773 & & \\
\hline & & OI3 & $.885^{* * * *}$ & 21.198 & .783 & & \\
\hline & & OI4 & $.761^{* * *}$ & 16.341 & .579 & & \\
\hline & & OI5 & $.860^{* * * *}$ & 20.120 & .740 & & \\
\hline & & OI6 & $.886^{* * *}$ & 21.256 & 0.786 & & \\
\hline & & OI7 & $.888^{* * *}$ & 21.360 & .789 & & \\
\hline & & OI8 & $.842^{* * *}$ & 19.327 & .709 & & \\
\hline & & OI9 & $.764^{* * * *}$ & 16.490 & .584 & & \\
\hline \multirow{5}{*}{$\begin{array}{l}\text { Organizational } \\
\text { Performance }\end{array}$} & \multirow{5}{*}{5} & OP1 & $.856^{* * *}$ & f.p. & .733 & \multirow{5}{*}{.713} & \multirow{5}{*}{.926} \\
\hline & & OP2 & $.841^{* * *}$ & 18.911 & .708 & & \\
\hline & & OP3 & $.862^{* * *}$ & 19.715 & .743 & & \\
\hline & & OP4 & $.802^{* * * *}$ & 17.485 & .644 & & \\
\hline & & OP5 & $.861^{* * * *}$ & 19.665 & .741 & & \\
\hline
\end{tabular}

Note: ${ }^{*} \mathrm{p}<.05,{ }^{* *} \mathrm{p}<.01,{ }^{*}{ }^{* *} \mathrm{p}<.001$ (two-tail), $\mathrm{n}=314, \mathrm{R}^{2}=$ reliability, C.R.=Compound Reliability, AVE=Average Variance Extracted, f.p.=fixed parameter. 
This study calculates reliability of measures using Bagozzi \& Yi (1988) composite reliability index and Fornell \& Larcker (1981) average variance extracted index. For all the measures both indices are higher than the evaluation criteria, namely .60 for the composite reliability index and .50 for the average variance extracted index (Bagozzi \& Yi, 1988). In all cases, the CRs are above the minimum threshold of .70 (from .911 to .958), indicating that we have reliability in our factors. Besides, for all factors, the AVEs are from .531 to .772. All items load on their hypothesized factors (See Table 3) and the estimates are positive and significant (the lowest t-value is 10.863), which provides evidence of convergent validity (Bagozzi \& Yi, 1988). Finally, the confidence interval ( \pm 2 S.E.) around the estimated correlation between any two latent indicators never includes 1.0. These results support discriminant validity (Anderson \& Gerbing, 1988).

\subsection{Hypothesis testing}

This section presents the main results of the hypothesis testing of the structural relationship among the latent variables (Table 4, 5 and Figure 3).

Figure 3 shown the standardized structural coefficients. The relative importance of the variables is reflected through the magnitude of the coefficients. Fitness indexes of structural model represents an accepted level of structural model's fitness $\left(\chi^{2}(421)=484.541, p=.017\right.$, GFI=.909, CFI=.991, IFI=.991, TLI=.990, RMSEA=.022).

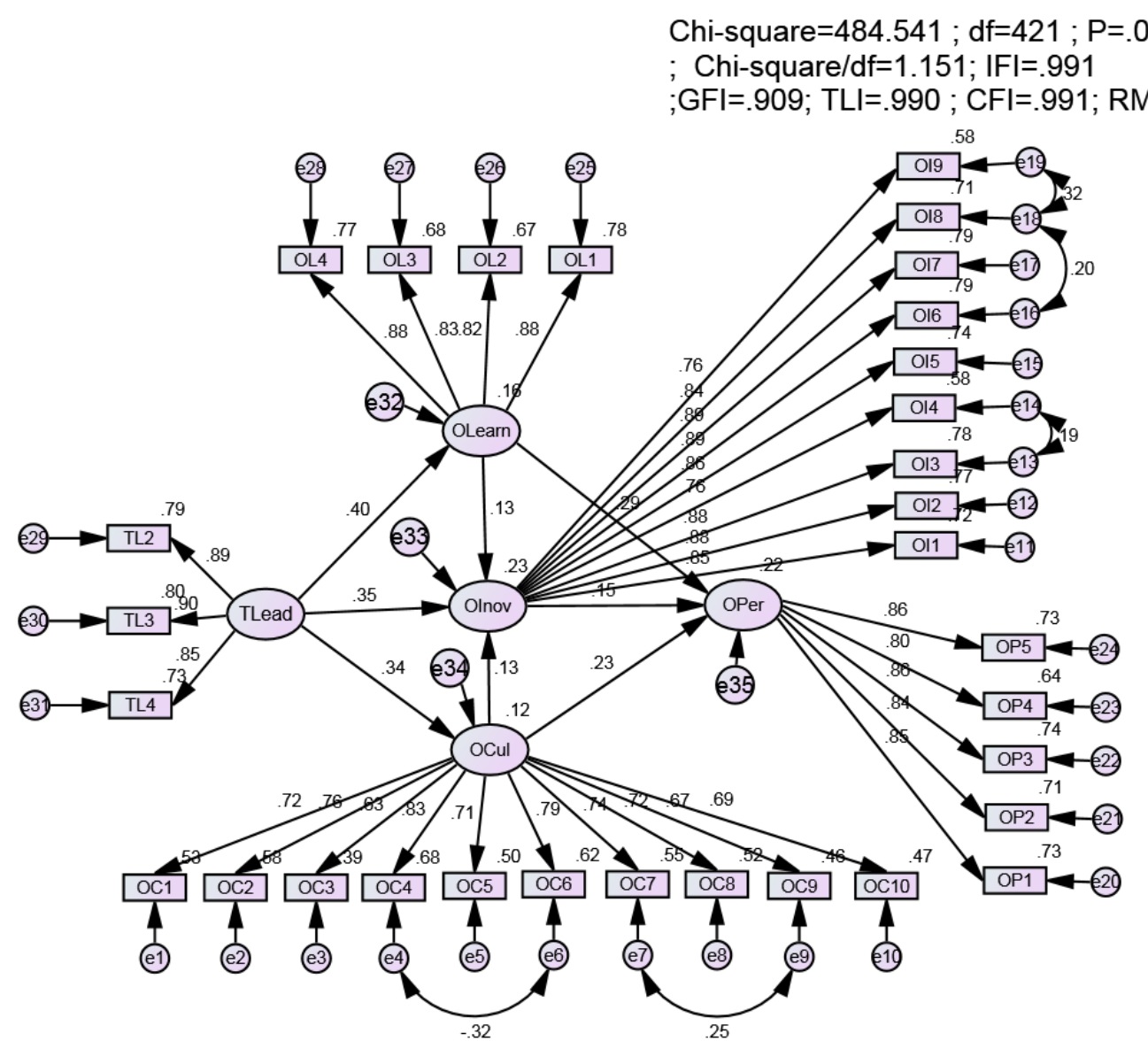

Figure 3. Results of Structural Equation Model

Table 4 presents the results for the structural model in Figure 3. Structural equation modeling was performed to examine the direct and indirect effects of the independent variables of Transformational Leadership, Organizational Learning, Organizational 
Innovation, and Organizational Culture on the performance of an organization. Indirect effects are indicated as a simple multiplicative measure of the magnitude of sequential beta weights (Asher, 1976), while total effects are calculated as the sum of direct and indirect effects (Pedhazur, 1997). Each equation or test for multicollinearity, linearity, normality, and homoscedasticity was controlled and no problem conflicted.

Findings from the standardized regression coefficients (Table 4) shown that Transformational Leadership is closely related to and affects Organizational Learning $\left(\beta_{11}=.397\right)$, Organizational Culture $\left(\beta_{12}=.341\right)$ and Organizational Innovation $\left(\beta_{13}=.350\right)$, as predicted in hypotheses 1, 2 and 3, respectively. Moreover, the results show an indirect effect of Transformational Leadership on Organizational Innovation (.098) by Organizational Learning and Organizational Culture (.397x.134x.131). Thus, the overall influence of Transformational Leadership on Organizational Innovation is .447. We compared the magnitudes of these effects. The result indicated that total effect of Transformational Leadership on Organizational Innovation is larger than the effect of Organizational Learning and Organizational Culture on Organizational Innovation. Overall, the model elucidated Organizational Learning and Organizational Culture well.

Organizational Learning and Organizational Culture directly influence Organizational Innovation $\left(\beta_{21}=.131\right.$ and $\left.\beta_{22}=.134\right)$, supporting hypotheses 4 and 5. Finally, the research finds out a significant relationship between Organizational Performance and the whole Organizational Learning $\left(\beta_{31}=.286\right)$, Organizational Innovation $\left(\beta_{32}=.147\right)$ and Organizational Culture $\left(\beta_{33}=.235\right)$, supporting hypotheses 6,7 and 8 , respectively.

Table 5 also shows an indirect effect (.019) of Organizational Learning on Organizational Performance by Organizational Innovation (.131x.286). Therefore, the total effect of Organizational Learning on Organizational Performance is .305. Besides, there is an indirect effect (.020) of Organizational Culture on Organizational Performance by Organizational Innovation (.134x.235). And thus, the total effect of Organizational Culture on Organizational Performance is .254. The magnitudes of these effects were compared. The result showed that the total effect of Organizational Learning on Organizational Performance is larger than the effect of Organizational Innovation on Organizational Performance. The finding also indicated that the total effect of Organizational Culture on Organizational Performance is larger than the effect of Organizational Innovation on Organizational Performance. Overall, the model elucidated innovation well. In addition to these effects, the research indicated an indirect relationship between Transformational Leadership and Organizational Performance (.259).

Table 4.The structural model result (direct, indirect and total effects)

\begin{tabular}{|c|c|c|c|c|}
\hline Effect from & To & Direct effects & $\begin{array}{l}\text { Indirect } \\
\text { effects }\end{array}$ & $\begin{array}{l}\text { Total } \\
\text { effects }\end{array}$ \\
\hline Transformational Leadership & Organizational Learning & .397 & & .397 \\
\hline Transformational Leadership & Organizational Culture & .341 & & .341 \\
\hline Transformational Leadership & Organizational Innovation & .350 & .098 & .447 \\
\hline Transformational Leadership & Organizational Performance & & .259 & .259 \\
\hline Organizational Learning & Organizational Innovation & .131 & & .131 \\
\hline Organizational Learning & Organizational Performance & .286 & .019 & .305 \\
\hline Organizational Culture & Organizational Innovation & .134 & & .134 \\
\hline Organizational Culture & Organizational Performance & .235 & .020 & .254 \\
\hline Organizational Innovation & Organizational Performance & .147 & & .147 \\
\hline Goodness of fit statistics & \multicolumn{4}{|c|}{$\begin{array}{l}\chi^{2}(421)=484.541 \mathrm{p}=0.017 \chi^{2} / \mathrm{df}=1.151 \mathrm{IFI}=.991 \mathrm{GFI}=.909 \mathrm{TLI}=.990 \mathrm{CFI}=.991 \\
\text { RMSEA }=.022\end{array}$} \\
\hline
\end{tabular}




\section{Conclusion and future research}

We conducted this study to examine how Transformational Leadership of leader correlates with Organizational Learning, Innovation and Culture, and how each predicts Organizational Performance in challenging and uncertain conditions. It seems fair to say that it took Transformational Leadership to be successful in this performance context. This study is built to such Organizational Performance improvement by indicating the strategic role of Organizational Learning, Organizational Innovation, and Organizational Culture. Controlling these variables gives rise to organization's values that are very difficult to copy. Especially, the results of analysis support all of the hypotheses, indicating that a leader style of Transformational Leadership through Organizational Learning, Organizational Innovation, and Organizational Culture simultaneously affects Organizational Performance.

First, we developed and checked a model that combines the theories of Transformational Leadership and performance. Although some of past studies have found the relationship between Transformational Leadership and performance (Aragón-Correa et al., 2007a, Birasnav, 2014, García-Morales et al., 2008, McColl-Kennedy \& Anderson, 2002, Ogbonna \& Harris, 2000), this is the first work that finds out the direct and indirect effects of Transformational Leadership on Organizational Performance in manufacturing firm context. The reason is that organizations in the field of manufacturing have clear outcome, thus, the main devotement of this work is this model, which has a strong theoretical foundation and can be used to assess the effects of this leadership style on Organizational Performance based on manufacturing firms' data in Vietnam. Moreover, our study contributes to filling the theoretical gaps by proposing a model discussing the influence of Transformational Leadership on Organizational Learning, Innovation and Culture, which in turn, leads to Organizational Performance in a model. The empirical findings verified the relationships between variables of the theoretical model, and all hypotheses are statistically supported. Through direct and indirect analysis, the study provides a possible mechanism by which Transformational Leadership practices contribute to Organizational Performance. The mediating roles of factors in the relationship between Transformational Leadership and Organizational Performance, as suggested by García-Morales et al., (2012), for future research are also confirmed. The implication is that Transformational Leadership practices will yield significant effects to Organizational Performance directly or indirectly through improving Organizational Learning, Innovation, and Culture.

Second, the study performs a positive association between Transformational Leadership and Organizational Learning, Organizational Innovation and Organizational Culture. This leadership style manages an organization through sharing and transferring knowledge (Organizational Learning), creates new knowledge when applied (innovation) (Nonaka \& Takeuchi, 1995, Senge, 1999). Thus, Transformational Leadership propels Organizational Learning which seeks and establishes a path for great development that gives sustainable advantages through innovation (Senge, 1999). Moreover, Transformational Leadership should try to promote cultural changes in an organization through understanding and appreciating the "interweaving of continuity and change" for long term purposes and values which provide reinforcement for innovative efforts (Bass \& Avolio, 1993).

Third, the study also verifies a positive direct and indirect association between Transformational Leadership and innovation through Organizational Learning and Organizational Culture. The results demonstrate the importance of Transformational Leadership in creating innovation.

Fourth, the study demonstrates empirically a positive relationship between Organizational Learning and innovation as well as Organizational Culture and innovation. Through learning, the organization can improve the innovation capacity, change behavior and thus can renew and reinvent its technology and production (Argyris \& Schon, 1995). 
Organizational Learning encourages continuous innovation. Moreover, regarding the culture innovation link, the results indicate that Organizational Culture is a key determinant for Organizational Innovation (Naranjo-Valencia et al., 2016).

Fifth and finally, our results show that increases in sharing and transferring knowledge (Organizational Learning), Organizational Innovation and Organizational Culture are all related to increases in Organizational Performance, especially in the field of manufacturing research. As predicted, our findings reveal that sharing and transferring knowledge can enhance both innovation and Organizational Performance. Simultaneously, culture is directly and indirectly related to performance through innovation. Culture creates favorable conditions for innovation, is an important key to improving performance. This is the first work that examines the mediating roles of Organizational Learning, innovation, and culture in the relationship between Transformational Leadership and Organizational Performance in the manufacturing firms.

The current study has several limitations. First, the present results are based on the responses of CEOs (single respondents), which relate a certain degree of subjectivity. We used CEOs' responses because they can have a profound knowledge of these strategic variables. The research follows the methods that were used in the past by other authors. However, this study can use the response of the subordinates or immediate leaders in order to have more accurate results. A second limitation of this research concerns the measures of Transformational Leadership. Although, the majority of other studies also survey CEOs or managers and self-reports of leadership are valid measures (Egri \& Herman, 2000, GarcíaMorales et al., 2008, Yukl, 2013), sending questionnaires to all other members of the organization would be essential to verify their leaders' behavior. Finally, the study only analyzes the relationship between Transformational Leadership and Organizational Performance through three mediating variables (Organizational Learning, Organizational Innovation, Organizational Culture). Although these variables explain an acceptable amount of variance in performance, the study can analyze other intermediate variables, such as culture differences, sharing knowledge, cultural conflicts, etc. Future studies might also investigate other intermediate effects in the relationship between Transformational Leadership and Organizational Performance or examine in another context.

\section{Acknowledgement}

The authors would like to thank the Editor-in-chief and two anonymous reviewers for their constructive comments.

\section{References}

Anderson, J., \& Gerbing, D. W. (1988). Structural Equation Modeling in Practice: A Review and Recommended Two-Step Approach. Psychological Bulletin, 103(3), 411-423. https://doi.org/10.1037/0033-2909.103.3.411

Antoncic, B., \& Hisrich, R. D. (2001). Intrapreneurship: Construct refinement and crosscultural validation. Journal of Business Venturing, 16(5), 495-527. https://doi.org/10.1016/S0883-9026(99)00054-3

Aragón-Correa, J. A., García-Morales, V. J., \& Cordón-Pozo, E. (2007a). Leadership and organizational learning's role on innovation and performance: Lessons from Spain. Industrial Marketing $\quad$ Management, 36(3), 349-359. https://doi.org/10.1016/j.indmarman.2005.09.006

Aragón-Correa, J. A., García-Morales, V. J., \& Cordón-Pozo, E. (2007b). Leadership and organizational learning's role on innovation and performance: Lessons from Spain. 


Industrial Marketing Management, 36(3), 349-359.

https://doi.org/10.1016/j.indmarman.2005.09.006

Argyris, C., \& Schon, D. A. (1995). Organizational Learning II: Theory, Method, and Practice (F First Edition edition). Reading, Mass: FT Press.

Asher, H. (1976). Causal Modeling (Quantitative Applications in the Social Sciences) (Beverley Hills). Retrieved from https://www.amazon.com/Causal-ModelingQuantitative-Applications-Sciences/dp/0803906544

Athena Xenikou, \& Maria Simosi. (2006). Organizational culture and transformational leadership as predictors of business unit performance. Journal of Managerial Psychology, 21(6), 566-579. https://doi.org/10.1108/02683940610684409

Bagozzi, R. P., \& Yi, Y. (1988). On the evaluation of structural equation models. Journal of the Academy of Marketing Science, 16(1), 74-94. https://doi.org/10.1007/BF02723327

Baker, W. E., \& Sinkula, J. M. (1999). The synergistic effect of market orientation and learning orientation on organizational performance. Journal of the Academy of Marketing Science, 27(4), 411-427. https://doi.org/10.1177/0092070399274002

Barczak, G., \& Wilemon, D. (1992). Successful new product team leaders. Industrial Marketing Management, 21(1), 61-68. https://doi.org/10.1016/0019-8501(92)90034-Q

Bass, B. M. (1990). From transactional to transformational leadership: Learning to share the vision. Organizational Dynamics, 18(3), 19-31. https://doi.org/10.1016/00902616(90)90061-S

Bass, B. M. (1995). Theory of transformational leadership redux. The Leadership Quarterly, 6(4), 463-478. https://doi.org/10.1016/1048-9843(95)90021-7

Bass, B. M. (1999). Two decades of research and development in transformational leadership. European Journal of Work and Organizational Psychology, 8(1), 9-32. https://doi.org/10.1016/1048-9843(95)90021-7

Bass, B. M., \& Avolio, B. J. (1993). Transformational Leadership and Organizational Culture. Public Administration Quarterly, 17(1), 112-121.

Bass, B. M., \& Avolio, B. J. (2000). MLQ, Multifactor Leadership Questionnaire Sampler Set: Technical Report, Leader Form, Rater Form, and Scoring Key for MLQ Form $5 x$ short. Mind Garden.

Bass, B. M., Avolio, B. J., Jung, D. I., \& Berson, Y. (2003). Predicting unit performance by assessing transformational and transactional leadership. Journal of Applied Psychology, 88(2), 207. https://doi.org/10.1037/0021-9010.88.2.207

Bentler, P. M., \& Bonett, D. G. (1980). Significance tests and goodness of fit in the analysis of covariance structures. Psychological Bulletin, 88(3), 588-606. https://doi.org/10.1037/0033-2909.88.3.588

Birasnav, M. (2014). Knowledge management and organizational performance in the service industry: The role of transformational leadership beyond the effects of transactional leadership. Journal of Business Research, 67(8), 1622-1629. https://doi.org/10.1016/j.jbusres.2013.09.006

Brockman, B. K., \& Morgan, R. M. (2003). The Role of Existing Knowledge in New Product Innovativeness and Performance. Decision Sciences, 34(2), 385-419. https://doi.org/10.1111/1540-5915.02326

Brown, S. L., \& Eisenhardt, K. M. (1995). Product Development: Past Research, Present Findings, and Future Directions. The Academy of Management Review, 20(2), 343-378. https://doi.org/10.2307/258850

Browne, M. W., \& Cudeck, R. (1992). Alternative Ways of Assessing Model Fit. Sociological Methods \& Research, 21(2), 230-258. https://doi.org/10.1177/0049124192021002005

Burns, J. M. (1978). Leadership. New York: Harper \& Row.

Büschgens, T., Bausch, A., \& Balkin, D. B. (2013). Organizational culture and innovation : a 
meta-analytic review. The Journal of Product Innovation Management: An International Publication of the Product Development \& Management Association, $30(4)$.

Cefis, E., \& Marsili, O. (2005). A matter of life and death: innovation and firm survival. Industrial and Corporate Change, 14(6), 1167-1192. https://doi.org/10.1093/icc/dth081

Chang, J., Bai, X., \& Li, J. J. (2015). The influence of leadership on product and process innovations in China: The contingent role of knowledge acquisition capability. Industrial Marketing Management, 50, 18-29. https://doi.org/10.1016/j.indmarman.2015.04.014

Chin, W. W., Marcolin, B. L., \& Newsted, P. R. (2003). A Partial Least Squares Latent Variable Modeling Approach for Measuring Interaction Effects: Results from a Monte Carlo Simulation Study and an Electronic-Mail Emotion/Adoption Study. Information Systems Research, 14(2), 189-217. https://doi.org/10.1287/isre.14.2.189.16018

Cohen, W. M., \& Levinthal, D. A. (1990). Absorptive Capacity: A New Perspective on Learning and Innovation. Administrative Science Quarterly, 35(1), 128-152. https://doi.org/10.2307/2393553

Coyne, K. P. (1986). Sustainable competitive advantage-What it is, what it isn't. Business Horizons, 29(1), 54-61. https://doi.org/10.1016/0007-6813(86)90087-X

Damanpour, F. (1991). Organizational Innovation: A Meta-Analysis of Effects of Determinants and Moderators. The Academy of Management Journal, 34(3), 555-590. https://doi.org/10.2307/256406

Denison, D. R. (1990). Corporate culture and organizational effectiveness. Retrieved from http://onlinelibrary.wiley.com/doi/10.1002/hrm.3930280408/abstract

Deshpandé, R., Farley, J. U., \& Jr, F. E. W. (1993). Corporate Culture, Customer Orientation, and Innovativeness in Japanese Firms: A Quadrad Analysis. Retrieved from http://www.hbs.edu/faculty/Pages/item.aspx?num=2651

Dewar, R. D., \& Dutton, J. E. (1986). The Adoption of Radical and Incremental Innovations: An Empirical Analysis. Management Science, 32(11), 1422-1433.

Dibella, A. J., Nevis, E. C., \& Gould, J. M. (1996). Understanding Organizational Learning Capability. Journal of Management Studies, 33(3), 361-379. https://doi.org/10.1111/j.1467-6486.1996.tb00806.x

E.C. Martins, \& F. Terblanche. (2003). Building organisational culture that stimulates creativity and innovation. European Journal of Innovation Management, 6(1), 64-74. https://doi.org/10.1108/14601060310456337

Egri, C. P., \& Herman, S. (2000). Leadership in the North American Environmental Sector: Values, Leadership Styles, and Contexts of Environmental Leaders and Their Organizations. The Academy of Management Journal, 43(4), 571-604. https://doi.org/10.2307/1556356

Elkins, T., \& Keller, R. T. (2003). Leadership in research and development organizations: A literature review and conceptual framework. The Leadership Quarterly, 14(4-5), 587606. https://doi.org/10.1016/S1048-9843(03)00053-5

Fiol, C. M., \& Lyles, M. A. (1985). Organizational Learning. The Academy of Management Review, 10(4), 803-813. https://doi.org/10.2307/258048

Fornell, C., \& Larcker, D. F. (1981). Evaluating Structural Equation Models with Unobservable Variables and Measurement Error. Journal of Marketing Research, 18(1), 39-50. https://doi.org/10.2307/3151312

García-Morales, V. J., Llorens-Montes, F. J., \& Verdú-Jover, A. J. (2006). Antecedents and consequences of organizational innovation and organizational learning in entrepreneurship. Industrial Management \& Data Systems, 106(1), 21-42. https://doi.org/10.1108/02635570610642940 
García-Morales, Víctor J., Lloréns-Montes, F. J., \& Verdú-Jover, A. J. (2008). The Effects of Transformational Leadership on Organizational Performance through Knowledge and Innovation*. British Journal of Management, 19(4), 299-319. https://doi.org/10.1111/j.1467-8551.2007.00547.x

García-Morales, Víctor J., Ruiz-Moreno, A., \& Llorens-Montes, F. J. (2007). Effects of Technology Absorptive Capacity and Technology Proactivity on Organizational Learning, Innovation and Performance: An Empirical Examination. Technology Analysis \& Strategic Management, 19(4), 527-558. https://doi.org/10.1080/09537320701403540

García-Morales, Víctor Jesús, Jiménez-Barrionuevo, M. M., \& Gutiérrez-Gutiérrez, L. (2012). Transformational leadership influence on organizational performance through organizational learning and innovation. Journal of Business Research, 65(7), 1040 1050. https://doi.org/10.1016/j.jbusres.2011.03.005

Gordon, G. G., \& DiTomaso, N. (1992). Predicting Corporate Performance from Organizational Culture*. Journal of Management Studies, 29(6), 783-798. https://doi.org/10.1111/j.1467-6486.1992.tb00689.x

Gunday, G., Ulusoy, G., Kilic, K., \& Alpkan, L. (2011). Effects of innovation types on firm performance. International Journal of Production Economics, 133(2), 662-676. https://doi.org/10.1016/j.ijpe.2011.05.014

Hage, J. (1980). Theories of Organizations: Form, Process, and Transformation. Wiley.

Hartmann, A. (2006). The role of organizational culture in motivating innovative behaviour in construction firms. Construction Innovation, 6(3), 159-172.

Hofstede, G., \& Bond, M. H. (1988). The Confucius connection: From cultural roots to economic growth. Organizational Dynamics, 16(4), 5-21. https://doi.org/10.1016/00902616(88)90009-5

Jiménez-Jiménez, D., \& Sanz-Valle, R. (2011). Innovation, organizational learning, and performance. Journal of Business Research, 64(4), 408-417. https://doi.org/10.1016/j.jbusres.2010.09.010

Kalmuk, G., \& Acar, A. Z. (2015). The Mediating Role of Organizational Learning Capability on the Relationship Between Innovation and Firm's Performance: A Conceptual Framework. Procedia - Social and Behavioral Sciences, 210, 164-169. https://doi.org/10.1016/j.sbspro.2015.11.355

Kotter, J. P., \& Heskett, J. L. (2011). Corporate Culture and Performance. Retrieved from http://books.simonandschuster.com/Corporate-Culture-and-Performance/John-PKotter/9781451655322

Lau, C., \& Ngo, H. (2004). The HR system, organizational culture, and product innovation. International Business Review, 13(6), 685-703. https://doi.org/10.1016/j.ibusrev.2004.08.001

Lin, H.-E., McDonough, E. F., Lin, S.-J., \& Lin, C. Y.-Y. (2013). Managing the Exploitation/Exploration Paradox: The Role of a Learning Capability and Innovation Ambidexterity. Journal of Product Innovation Management, 30(2), 262-278. https://doi.org/10.1111/j.1540-5885.2012.00998.x

Lyon, D. W., \& Ferrier, W. J. (2002). Enhancing Performance With Product-Market Innovation: The Influence Of The Top Management Team. Journal of Managerial Issues, 14(4), 452-469.

Maani, K., \& Benton, C. (1999). Rapid team learning: Lessons from team New Zealand America's cup campaign. Organizational Dynamics, 27(4), 48-62. https://doi.org/10.1016/S0090-2616(99)90029-3

Manz, C., Barstein, D., Hostager, T., \& Shapiro, G. (1989). Leadership and innovation: a longitudinal process view. In: Van de Ven A, Angle HL, Poole MS, editors. $H$ on the Management of Innovation: The Minnesota Studies. https://doi.org/10.1016/0090- 
2616(90)90061-S

McColl-Kennedy, J. R., \& Anderson, R. D. (2002). Impact of leadership style and emotions on subordinate performance. The Leadership Quarterly, 13(5), 545-559. https://doi.org/10.1016/S1048-9843(02)00143-1

Mhatre, K. H., \& Riggio, R. E. (2014). Charismatic and Transformational Leadership. The Oxford Handbook of Leadership and Organizations. https://doi.org/10.1093/oxfordhb/9780199755615.013.012

Miron, E., Erez, M., \& Naveh, E. (2004). Do personal characteristics and cultural values that promote innovation, quality, and efficiency compete or complement each other? Journal of Organizational Behavior, 25(2), 175-199. https://doi.org/10.1002/job.237

Murray, J. Y., \& Kotabe, M. (1999). Sourcing strategies of U.S. service companies: a modified transaction-cost analysis. Strategic Management Journal, 20(9), 791-809. https://doi.org/10.1002/(SICI)1097-0266(199909)20:9<791::AID-SMJ49>3.0.CO,2-U

Naranjo-Valencia, J. C., Jiménez-Jiménez, D., \& Sanz-Valle, R. (2016). Studying the links between organizational culture, innovation, and performance in Spanish companies. Revista Latinoamericana de Psicología, 48(1), 30-41. https://doi.org/10.1016/j.rlp.2015.09.009

Nguyen, T. T., Mia, L., Winata, L., \& Chong, V. K. (2017). Effect of transformationalleadership style and management control system on managerial performance. Journal of Business Research, 70, 202-213. https://doi.org/10.1016/j.jbusres.2016.08.018

Nonaka, I., \& Takeuchi, H. (1995). The Knowledge-creating Company: How Japanese Companies Create the Dynamics of Innovation. Oxford University Press.

Ogbonna, E., \& Harris, L. C. (2000). Leadership style, organizational culture and performance: empirical evidence from UK companies. International Journal of Human Resource Management, 11(4), 766-788.

Pedhazur, E. J. (1997). Multiple Regression in Behavioral Research: Explanation and Prediction. Harcourt Brace College Publishers.

Podsakoff, P. M., MacKenzie, S. B., \& Bommer, W. H. (1996). Transformational leader behaviours and substitutes for leadership as determinants of employee satisfaction, commitment, trust, organizational citizenship behaviours. Journal of Management, 22(2), 259-298. https://doi.org/10.1016/1048-9843(95)90021-7

Quinn, J. B. (1986). Innovation and Corporate Strategy: Managed Chaos A2 - Horwitch, Mel. In Technology in the Modern Corporation (pp. 167-183). Retrieved from http://www.sciencedirect.com/science/article/pii/B9780080342399500153

Saffold, G. S. (1988). Culture Traits, Strength, and Organizational Performance: Moving beyond "Strong" Culture. The Academy of Management Review, 13(4), 546-558. https://doi.org/10.2307/258374

Salvato, C. (2009). Capabilities Unveiled: The Role of Ordinary Activities in the Evolution of Product Development Processes. Organization Science, 20(2), 384-409. https://doi.org/10.1287/orsc. 1080.0408

Samad, S. (2012). The Influence of Innovation and Transformational Leadership on Organizational Performance. Procedia - Social and Behavioral Sciences, 57, 486-493. https://doi.org/10.1016/j.sbspro.2012.09.1215

Schein, E. H. (2010). Organizational Culture and Leadership. John Wiley \& Sons.

Scott, S. G., \& Bruce, R. A. (1994). Determinants of Innovative Behavior: A Path Model of Individual Innovation in the Workplace. The Academy of Management Journal, 37(3), 580-607. https://doi.org/10.2307/256701

Senge, P. M. (1999). The Fifth Discipline: The Art \& Practice of The Learning Organization. New York: Random House Audio.

Shao, Z., Feng, Y., \& Liu, L. (2012). The mediating effect of organizational culture and 
knowledge sharing on transformational leadership and Enterprise Resource Planning systems success: An empirical study in China. Computers in Human Behavior, 28(6), 2400-2413. https://doi.org/10.1016/j.chb.2012.07.011

Slater, S., \& Narver, J. (1995). Market orientation and the learning organization.

Syafii, L. I., Thoyib, A., Nimran, U., \& Djumahir. (2015). The Role of Corporate Culture and Employee Motivation as a Mediating Variable of Leadership Style Related with the Employee Performance (Studies in Perum Perhutani). Procedia - Social and Behavioral Sciences, 211, 1142-1147. https://doi.org/10.1016/j.sbspro.2015.11.152

Thomson, N. B., Rawson, J. V., Slade, C. P., \& Bledsoe, M. (2016). Transformation and Transformational Leadership: A Review of the Current and Relevant Literature for Academic Radiologists. Academic Radiology, 23(5), 592-599. https://doi.org/10.1016/j.acra.2016.01.010

Tippins, M. J., \& Sohi, R. S. (2003). IT competency and firm performance: is organizational learning a missing link? Strategic Management Journal, 24(8), 745-761. https://doi.org/10.1002/smj.337

Tushman, M., \& Nadler, D. (1986). Organizing for Innovation. California Management Review, 28(3), 74-92. https://doi.org/10.2307/41165203

Ulrich, D., Jick, T., \& Glinow, M. A. V. (1993). High-impact learning: Building and diffusing learning capability. Organizational Dynamics, 22(2), 52-66. https://doi.org/10.1016/0090-2616(93)90053-4

Ussahawanitchakit, P. (2008). Impacts of Organizational Learning on Innovation Orientation and Firm Efficiency: An Empirical Assessment of Accounting Firms in Thailand HighBeam Business: Arrive Prepared. International Journal of Business Research, 8(4), 1 .

Van de Ven, A. H. (1986). Central Problems in the Management of Innovation. Management Science, 32(5), 590-607.

Yasir, M., Imran, R., Irshad, M. K., Mohamad, N. A., \& Khan, M. M. (2016). Leadership Styles in Relation to Employees' Trust and Organizational Change Capacity: Evidence From Non-Profit Organizations. SAGE Open, 6(4), 2158244016675396. https://doi.org/10.1177/2158244016675396

Yuan L., Nguyen T.-T.-N., \& Vu M.-C. (2017). The Mediating Effect of Trust and Commitment on Transformational Leadership and Performance: An Empirical Study in Vietnam. International Journal of Information and Management Sciences, 28(3), 253275. https://doi.org/10.6186/IJIMS.2017.28.3.5

Yukl, G. (2013). Leadership in Organizations Global Edition. Pearson Education Limited.

Zollo, M., \& Winter, S. (2002). Deliberate learning and the evolution of dynamic capabilities. Organization Science, 13(3), 339-351. 